\title{
rs10757278 (9p21 region) affects the risk of arterial thrombosis in male individuals from the state of anzoátegui, Venezuela
}

\author{
Yanireth Jimenez', Merlyn Vívenes de Lugo² and Dinorah Castro de Guerra ${ }^{1 *}$ \\ *Correspondence: dinorah_castro@hotmail.com \\ 1 Venezuelan Scientific Research Institute, Center for Experimental Medicine, Human Genetics Laboratory, Venezuela. \\ 2University of East Bioanalysis Department, Sucre State, Venezuela.
}

\begin{abstract}
Background: Numerous single nucleotide polymorphisms (SNPs) located in chromosomal region 9p21 have been associated with cardiovascular disease, most of these studies in European populations. We have no knowledge of studies conducted in admixed populations populations as the Latin Americans. For this reason we decided to study the association of SNPs rs2383206, rs10757274 and rs10757278, together with some non-genetic factors with arterial thrombotic events (AT), in individuals from the north-eastern portion of Venezuela.

Methods: Gender, age and non-genetic risk variables were evaluated in 119 patients with AT and 119 control subjects. Genotypes were identified using TaqMan probes. The odds ratio (OR) for genotypes alone and in conjunction with non-genetic variables were estimated.

Results: There was a consistent association of rs 10757278 with AT, increased in males (OR=2.38). The medium-low socioeconomic status also confers a significant risk for AT in both sexes $(\mathrm{OR}=4.04)$. Haplotypes with at least two A alleles, proved to be protective $(\mathrm{OR}=0.53)$ in developing arterial thrombosis.

Conclusions: There was a consistent association with AT for the rs10757278 polymorphism, increased in males. Sex and socioeconomic status were also significant risk factors in this study reinforcing the importance in studying other variables such as environmental and sex differences together with the genetic structure of each population when analyzing risks for AT diseases. These results serve as a guide when searching for markers of risk for this disease common in Venezuela.
\end{abstract}

Keywords: Chromosome 9p21, arterial thrombosis, Venezuelan population

\section{Introduction}

Many SNPs have been identified in the chromosomal region 9p21 associated with cardiovascular disease [1-4] but most of these studies have been conducted in Europeans or their descendants. The Venezuelan population has shown a significant genetic heterogeneity within and between various regions of the country [5-7] which influences the distribution of different polymorphisms and the synergetic effect between them. For this reason, we studied the association of different SNPs in the chromosomal region 9p21, with arterial thrombotic events (AT) and present here results for three SNPs (rs2383206, rs10757274, rs10757278) in individuals with grandparents from the state of Anzoátegui, in the north-eastern portion of Venezuela.

\section{Methods}

\section{Study sample and genotyping}

Patients with AT ( $\mathrm{N}=119)$ from hospitals Luis Razetti and Guzman Lander in Anzoátegui, were studied between November 2010 and January 2011. As a control group we selected individuals with no history of AT ( $\mathrm{N}=119)$ from a geriatric center and among those attending the hospital Luis Razetti for laboratory analyses. All subjects were biologically unrelated, with parents and grandparents born in Anzoátegui, in order to reduce genetic heterogeneity. Additionally, we selected a group of individuals from the general population $(\mathrm{N}=59)$ as a genetic control. In all (cases, controls and general population) the distribution of three STRs, located on different chromosomes (F13A01, VWA, FES/FPS) was studied in order to investigate the possibility of population stratification.

In addition to age and sex in cases and controls, some biochemical (hypertension, total cholesterol, LDL, VLDL and HDL, diabetes mellitus), anthropometric (body mass index and waist circumference) and environmental (smoking habits and socioeconomic status) risk variables were evaluated. An informed consent approved by the Bioethics Committee of IVIC was signed by all participants in the study.

Genotypes were obtained by real-time PCR using TaqMan probes (Applied Biosystems).

\section{Statystical analysis}

The allele frequencies were estimated by direct counting. The adjustment to Hardy-Weinberg (HW) equilibrium was studied by a Chi-square test with the MAXLIK program [8]. MedCalc software (Windows, version 11.6.1.0) [9] was used to study: 
Jimenez et al. Journal of Genetics Study 2013,

http://www.hoajonline.com/journals/pdf/2054-1112-1-1.pdf

doi: 10.7243/2054-1112-1-1

Table 1. Genotypic and allelic frequencies with OR values.

\begin{tabular}{|c|c|c|c|c|c|}
\hline SNPs & $\begin{array}{l}\text { Cases } \\
\mathrm{N}=119\end{array}$ & $\begin{array}{l}\text { Controls } \\
\mathrm{N}=119\end{array}$ & $P$ & $\begin{array}{l}\text { OR } \\
\text { (CI 95\%) }\end{array}$ & $P$ \\
\hline \multicolumn{6}{|l|}{ Genotypes } \\
\hline \multicolumn{6}{|l|}{ rs10757274 } \\
\hline $\mathrm{AA}$ & $40(33.61)$ & $45(37.82)$ & -- & \multirow{4}{*}{$\begin{array}{c}1.201 \\
(0.706-2.043)\end{array}$} & \multirow{4}{*}{0.588} \\
\hline AG & $62(52.10)$ & $54(45.38)$ & 0.580 & & \\
\hline GG & $17(14.29)$ & $20(16.81)$ & -- & & \\
\hline G & 40.34 & 39.5 & 0.926 & & \\
\hline \multicolumn{6}{|l|}{ rs2383206 } \\
\hline $\mathrm{AA}$ & $31(26.05)$ & $36(30.25)$ & -- & \multirow{4}{*}{$\begin{array}{c}0.778 \\
(0.387-1.562)\end{array}$} & \multirow{4}{*}{0.596} \\
\hline AG & $60(50.42)$ & $54(45.38)$ & 0.702 & & \\
\hline GG & $28(23.52)$ & $29(24.37)$ & -- & & \\
\hline G & 48.74 & 47.06 & 0.783 & & \\
\hline \multicolumn{6}{|l|}{ rs 10857278} \\
\hline $\mathrm{AA}$ & $38(31.93)$ & $52(43.70)$ & -- & \multirow{4}{*}{$\begin{array}{c}1.654 \\
(0.975-2.808)\end{array}$} & \multirow{4}{*}{0.082} \\
\hline AG & $63(52.94)$ & $48(40.34)$ & 0.121 & & \\
\hline GG & $18(15.13)$ & $19(15.97)$ & -- & & \\
\hline G & 41.53 & 36.25 & 0.277 & & \\
\hline Haplotypes & $\mathrm{N}=\mathbf{2 3 8}$ & $\mathrm{N}=\mathbf{2 3 8}$ & & & \\
\hline AAA & $113(47.47)$ & $111(46.63)$ & -- & 1 & -- \\
\hline GGG & $81(34.03)$ & 74(31.09) & -- & $\begin{array}{c}0.918 \\
(0.608-0.383)\end{array}$ & 0.681 \\
\hline $\begin{array}{l}\text { AGG, GAG Y } \\
\text { GGA }^{*}\end{array}$ & $23(09.66)$ & $16(06.72)$ & -- & $\begin{array}{c}1.412 \\
(0.708-2.814)\end{array}$ & 0.327 \\
\hline $\begin{array}{l}\text { AAG, AGA Y } \\
\text { GAA }^{* *}\end{array}$ & $20(08.40)$ & $37(15.54)$ & -- & $\begin{array}{c}0.531 \\
(0,290-0,971)\end{array}$ & 0.039 \\
\hline $\begin{array}{l}\text { AAG, AGG, } \\
\text { GAG Y GGG }\end{array}$ & $99(41.59)$ & $85(35.7)$ & -- & $\begin{array}{c}1.144 \\
(0.774-1.691)\end{array}$ & 0.499 \\
\hline
\end{tabular}

${ }^{\star}$ Haplotypes with two G alleles; ${ }^{\star \star}$ Haplotypes with two A alleles; \& Haplotypes with the G allele for rs10857278.

1- The association of AT with different genotypes of each of the three SNPs, using a Chi-square test. 2-The Odds Ratio (OR) for the G risk allele of each SNP to produce AT, assuming a dominant inheritance model. 3- An analysis of thrombotic risk through a logistic regression with inclusion of genetic and other risk factors used in this study: sex, age, biochemical, anthropometric and environmental variables. The goodness of fit of the model was assessed through the Hosmer-Lemeshow test and through the area under the ROC curve (AUC). For all tests a $p$-value $<0.05$ was considered statistically significant. The Bonferroni correction was made to correct for multiple comparisons. With the program ARLEQUIN (version 3.1) [10], linkage disequilibrium (LD) was explored performing a likelihood ratio test. Haplotypes were constructed for the three SNPs studied, using the maximum likelihood method from the Expectation-Maximization model.

\section{Results}

Non significant (NS) differences in the distributions of the STRs were observed between cases, controls and the general population, suggesting no genetic stratification in the samples.

Genotypes, allele frequencies and genotype risk values (OR) are shown in Table 1. All SNPs studied are in HW equilibrium in both groups. NS differences were obtained in allele and genotype frequencies between cases and controls; however, there was a clear trend in the three SNPs of an increased frequency of the $G$ allele (AG+GG genotypes) in patients with AT compared to controls. OR values obtained suggest that these SNPs, considered independently, do not confer a higher risk of AT, in contrast to what is published in previous studies $[11,12]$.

It has been reported that polymorphisms rs 10757274 , rs 1072383206 and rs10757278 are in LD [13]. The Arlequin analyses corroborates this statement, since LD was found to be significant ( $p \leq 0.0001)$ for all pair of loci. Because of this we carried out the risk analysis based on the distribution of haplotypes in both groups (Table 1). The haplotype AAA is distributed uniformly in both groups and GGG is predominant in cases but NS. It was also observed that in the presence of at least $2 \mathrm{G}$ alleles, there was a trend (NS) for increased AT risk, showing a possible interaction effect between these SNPs. However, haplotypes with two A alleles, show an inverse significant association with the disease $(\mathrm{OR}=0.53, \mathrm{p}=0.0399)$ in cases vs. controls, suggesting that the presence of two A alleles could have a protective effect against the disease.

Thrombotic processes are multifactorial events, a large number of genetic and non-genetic risk factors interact for triggering these pathologies. To analyze the influence in the occurrence of AT of the SNPs studied by us, taking into account other risk factors, we used a logistic regression model (Table 2). The results showed NS differences between cases and control groups for frequencies of the risk allele $G$ for each SNP studied independently. However, when analyzing the different polymorphisms simultaneously with non-genetic risk factors, we found that the highest risk is associated with non-genetic factors such as high concentration of fibrinogen ( $O R=2.2976, p=0.0246$ ) and medium-low socioeconomic status (OR: 3.4539, $p=0.0001$ ), whereas being female appears as a protective factor $(\mathrm{OR}=0.1229, \mathrm{p}=<0.0001)$.

The significant sex effect as a risk variable made us compute logistic regressions within each sex. Here we found that, for females, high concentrations of fibrinogen $(O R=3.0424)$, belonging to a medium-low socioeconomic status ( $\mathrm{OR}=$ 4.0456), and having family history of AT $(O R=3.1409)$, showed a significant increase in the risk of developing the disease. On the other hand, for males, the presence of genotypes A/G or G/G for rs 10757278 and belonging to a medium-low socioeconomic status ( $\mathrm{OR}=8.7325$ and $\mathrm{OR}=4.0455$, respectively) confer a significant elevated risk for the occurrence of AT.

Due to the increased risk shown by SNP rs 10757278 in men, it was decided to compare cases vs. controls within each sex, 
Jimenez et al. Journal of Genetics Study 2013,

Table 2. Logistic regression analysis of polymorphisms rs10757274, rs2383206, rs10757278, with different risk factors for arterial thrombosis.

\begin{tabular}{|c|c|c|c|}
\hline & OR & CI 95\% & $P$ \\
\hline \multicolumn{4}{|c|}{ Genetic and Nongenetic variables ${ }^{\star}$} \\
\hline \multicolumn{4}{|c|}{ Between groups (cases vs. controls) } \\
\hline Sex & 0.1229 & $0.0562-0.2687$ & $<0.0001$ \\
\hline Fibrinogen & 2.2976 & $1.1123-4.7459$ & 0.0246 \\
\hline Socioeconomic status & 3.4539 & $1.9422-6.1421$ & 0.0001 \\
\hline \multicolumn{4}{|l|}{ Within women } \\
\hline Fibrinogen & 3.2543 & $1.2543-8.4433$ & 0.0153 \\
\hline Socioeconomic status & 4.0296 & $1.6568-9.8007$ & 0.0021 \\
\hline History of arterial thrombosis & 3.0333 & $1.1623-7.9158$ & 0.0234 \\
\hline \multicolumn{4}{|l|}{ Within men } \\
\hline rs10757278 dominant model & 8.7325 & $2.0924-36.4452$ & 0.0030 \\
\hline Socioeconomic status & 4.0455 & $1.6138-10.1413$ & 0.0029 \\
\hline \multicolumn{4}{|c|}{ Only Genetic variables } \\
\hline \multicolumn{4}{|l|}{ Within women } \\
\hline rs10757274 & 0.8960 & $0.2868-2.7996$ & 0.8502 \\
\hline rs2383206 & 0.6357 & $0.2100-1.9240$ & 0.4227 \\
\hline rs10757278 & 1.4785 & $0.4503-4.8540$ & 0.5191 \\
\hline \multicolumn{4}{|l|}{ Within men } \\
\hline rs10757274 & 0.6582 & $0.2846-1.5224$ & 0.3283 \\
\hline rs2383206 & 0.9034 & $0.4364-1.8700$ & 0.7843 \\
\hline rs 10757278 & $2.3838^{*}$ & $1.0067-5.6449$ & 0.0482 \\
\hline
\end{tabular}

* Only significant results.

using only the SNPs as independent variables in the logistic regression. It was observed that being male and having the $\mathrm{G}$ allele for rs 10757278 confers a higher risk (OR=2.3838, $\mathrm{p}=0.04829$ ) to suffer AT whereas in females this OR is not significant. This risk is significantly higher for the group of males when combined with medium-low socioeconomic status ( $\mathrm{OR}=8.7325, \mathrm{p}=0.003)$, as described previously.

\section{Discussion}

The SNPs discovered through genome-wide studies, explain only a small fraction of the heritability of many diseases [14]. However, new data show advances which are producing new insights into gene-environment interaction through the use of association studies [15].

The study of gender differences in the association of polymorphisms to disease can provide a better understanding of gene-environment and gene-hormone interactions in men and women. In this work, as in previous association studies, the G allele of SNP rs 10857278 appears to confer an increased risk for AT in men [16], whereas in women, fibrinogen concentration is more important. Epidemiological data show that the risk of thrombosis is higher in men than in women up to the age of 60 [17], probably due to hormonal differences and to exposure to different risk factors involved in the physiopathology of the disease. This female protective effect was also observed in our study.

Socioeconomic status also proved to be a significant risk variable in the condition of thrombosis. The differences found between high and medium-low socioeconomic status could be revealing divergence between these groups regarding modifiable risk factors for AT such as nutrition, exercise, smoking and drinking habits among others.

Polymorphisms in chromosomal region 9p21 are located close to the tumor suppressor genes CDKN2A, CDKN2B and ANRIL, which have been associated with atherosclerosis because their expression may be modified by the presence of some SNPs risk alleles in this region $[18,19]$. The association of different SNPs in this chromosomal region with atherosclerotic disease in different ethnic groups, could be explained by possible differences in linkage disequilibrium patterns in these groups.

It has been reported a strong association between the polymorphisms rs 10757274 , rs2383206 and rs 10757278 and the onset of cardiovascular disease in African American and Hispanic individuals from USA, in Europeans and Asians $[\mathbf{1}, \mathbf{1 1}, \mathbf{1 2}, \mathbf{1 8 , 2 0 - 2 2}]$. However, little has been studied in Latin American individuals who have high genetic and cultural variability. Genetic heterogeneity has been reported at intra and inter-regional levels in Venezuela, and also between socioeconomic status $[6,7,23]$. It is important to determine whether these genetic differences could be influencing the distribution of SNPs in the 9p21 region and their effect on the incidence of AT. Ours is the first result reported for the 9 p21 region in Venezuelan patients, as part of a larger project which aims to analyze the relationship of different risk factors associated with this condition at a nationwide level. The study of a larger number of patients will provide more conclusive results.

\section{Conclusion}

There was a consistent association with AT for the rs 10757278 polymorphism, increased in males. Sex and socioeconomic status were also significant risk factors in this study reinforcing the importance in studying specific aspects such as environmental and sex differences together with the genetic structure of each population regarding AT diseases.

\section{Competing interest}

The authors declare that they have no competing interests.

\section{Authors' contributions}

\begin{tabular}{|l|c|c|c|}
\hline Authors' contributions & YJ & MV & DC \\
\hline Research concept and design & - & -- & $\sqrt{ }$ \\
\hline Collection and/or assembly of data & $\sqrt{ }$ & -- & -- \\
\hline Data analysis and interpretation & $\sqrt{ }$ & $\sqrt{ }$ & $\sqrt{ }$ \\
\hline Writing the article & $\sqrt{ }$ & -- & $\sqrt{ }$ \\
\hline Critical revision of the article & $\sqrt{ }$ & $\sqrt{ }$ & $\sqrt{ }$ \\
\hline Final approval of article & $\sqrt{ }$ & $\sqrt{ }$ & $\sqrt{ }$ \\
\hline Statistical analysis & $\sqrt{ }$ & -- & $\sqrt{ }$ \\
\hline
\end{tabular}

Acknowledgement and funding

Irene Paradisi for technical advice and Álvaro Rodríguez for 
Jimenez et al. Journal of Genetics Study 2013,

http://www.hoajonline.com/journals/pdf/2054-1112-1-1.pdf

doi: $10.7243 / 2054-1112-1-1$

comments on the manuscript. Funding LOCTI IVIC-899.

Publication history

Editor: Jimmy T. Efird, Brody School of Medicine, USA.

Received: 20-Aug-2013 Revised: 17-Sep-2013

Accepted: 30-Sep-2013 Published: 03-Oct-2013

\section{References}

1. Helgadottir A, Thorleifsson G, Manolescu A, Gretarsdottir S, Blondal T, Jonasdottir A, Sigurdsson A, Baker A, Palsson A, Masson G and Gudbjartsson DF et al. A common variant on chromosome 9p21 affects the risk of myocardial infarction. Science. 2007; 316:1491-3. | Article | PubMed

2. McPherson R, Pertsemlidis A, Kavaslar N, Stewart A, Roberts R, Cox DR, Hinds DA, Pennacchio LA, Tybjaerg-Hansen A, Folsom AR, Boerwinkle E, Hobbs $\mathrm{HH}$ and Cohen JC. A common allele on chromosome 9 associated with coronary heart disease. Science. 2007; 316:1488-91. | Article | PubMed Abstract | PubMed Full Text

3. Pasmant E, Laurendeau I, Heron D, Vidaud M, Vidaud D and Bieche I. Characterization of a germ-line deletion, including the entire INK4/ ARF locus, in a melanoma-neural system tumor family: identification of ANRIL, an antisense noncoding RNA whose expression coclusters with ARF. Cancer Res. 2007; 67:3963-9. | Article | PubMed

4. Rivera NV, Carreras-Torres R, Roncarati R, Viviani-Anselmi C, De Micco F, Mezzelani A, Koch W, Hoppmann P, Kastrati A and Stewart AF et al. Assessment of the 9p21.3 locus in severity of coronary artery disease in the presence and absence of type 2 diabetes. BMC Med Genet. 2013; 14:11. | Article | PubMed Abstract | PubMed Full Text

5. Rodríguez-Larralde A, Castro de Guerra D, González-Coira M and Morales J. Frecuencia genética y porcentaje de mezcla en diferentes áreas geográficas de Venezuela, de acuerdo a los grupos Rh y ABO. Interciencia. 2001; 26:8-12. | Website

6. Martinez H, Rodriguez-Larralde A, Izaguirre MH and De Guerra DC. Admixture estimates for Caracas, Venezuela, based on autosomal, Y-chromosome, and mtDNA markers. Hum Biol. 2007; 79:201-13. | Article | PubMed

7. Guerra DC, Perez CF, Izaguirre MH, Barahona EA, Larralde AR and Lugo MV. Gender differences in ancestral contribution and admixture in Venezuelan populations. Hum Biol. 2011; 83:345-61. | Article I PubMed

8. Reed TE and Schull WJ. A general maximum likelihood estimation program. Am J Hum Genet. 1968; 20:579-80. | PubMed Abstract | PubMed Full Text

9. MedCal for Windows. Statistics for biomedical research. Software. Versión 11.6. | Website

10. Excoffier L, Laval G and Schneider S. Arlequin (version 3.0): an integrated software package for population genetics data analysis. Evol Bioinform Online. 2005; 1:47-50. | Article | PubMed Abstract | PubMed Full Text

11. Shen GQ, Li L, Rao S, Abdullah KG, Ban JM, Lee BS, Park JE and Wang QK. Four SNPs on chromosome 9p21 in a South Korean population implicate a genetic locus that confers high cross-race risk for development of coronary artery disease. Arterioscler Thromb Vasc Biol. 2008; 28:360-5. | Article I PubMed

12. Zhang Q, Wang XF, Cheng SS, Wan XH, Cao FF, Li L, Chen XD, Liu WJ, Yang $X C$ and Jin L. Three SNPs on chromosome 9p21 confer increased risk of myocardial infarction in Chinese subjects. Atherosclerosis. 2009; 207:268. | Article | PubMed

13. Schunkert H, Gotz A, Braund P, McGinnis R, Tregouet DA, Mangino M, Linsel-Nitschke P, Cambien F, Hengstenberg $C$ and Stark K et al. Repeated replication and a prospective meta-analysis of the association between chromosome 9p21.3 and coronary artery disease. Circulation. 2008; 117:1675-84. | Article | PubMed Abstract | PubMed Full Text

14. Manolio TA, Collins FS, Cox NJ, Goldstein DB, Hindorff LA, Hunter DJ, McCarthy MI, Ramos EM, Cardon LR and Chakravarti A et al. Finding the missing heritability of complex diseases. Nature. 2009; 461:747-53. | Article | PubMed Abstract | PubMed Full Text
15. Cadwell K, Patel KK, Maloney NS, Liu TC, Ng AC, Storer CE, Head RD, Xavier R, Stappenbeck TS and Virgin HW. Virus-plus-susceptibility gene interaction determines Crohn's disease gene Atg16L1 phenotypes in intestine. Cell. 2010; 141:1135-45. | Article | PubMed Abstract | PubMed Full Text

16. Chen Z, Qian Q, Ma G, Wang J, Zhang X, Feng Y, Shen C and Yao Y. A common variant on chromosome 9p21 affects the risk of early-onset coronary artery disease. Mol Biol Rep. 2009; 36:889-93. | Article | PubMed

17. Liu LY, Schaub MA, Sirota M and Butte AJ. Sex differences in disease risk from reported genome-wide association study findings. Hum Genet 2012; 131:353-64. | Article | PubMed Abstract | PubMed Full Text

18. Broadbent HM, Peden JF, Lorkowski S, Goel A, Ongen H, Green F, Clarke R, Collins R, Franzosi MG, Tognoni G, Seedorf U, Rust S, Eriksson P, Hamsten A, Farrall $M$ and Watkins $H$. Susceptibility to coronary artery disease and diabetes is encoded by distinct, tightly linked SNPs in the ANRIL locus on chromosome 9p. Hum Mol Genet. 2008; 17:806-14. | Article | PubMed

19. Congrains A, Kamide K, Oguro R, Yasuda O, Miyata K, Yamamoto E, Kawai T, Kusunoki H, Yamamoto $\mathrm{H}$ and Takeya $\mathrm{Y}$ et al. Genetic variants at the 9p21 locus contribute to atherosclerosis through modulation of ANRIL and CDKN2A/B. Atherosclerosis. 2012; 220:449-55. | Article | PubMed

20. Assimes TL, Knowles JW, Basu A, Iribarren C, Southwick A, Tang H, Absher D, Li J, Fair JM, Rubin GD, Sidney S, Fortmann SP, Go AS, Hlatky MA, Myers RM, Risch N and Quertermous T. Susceptibility locus for clinical and subclinical coronary artery disease at chromosome 9p21 in the multi-ethnic ADVANCE study. Hum Mol Genet. 2008; 17:2320-8. | Article | PubMed Abstract | PubMed Full Text

21. Zhou L, Zhang $X$, He M, Cheng L, Chen Y, Hu FB and Wu T. Associations between single nucleotide polymorphisms on chromosome $9 \mathrm{p21}$ and risk of coronary heart disease in Chinese Han population. Arterioscler Thromb Vasc Biol. 2008; 28:2085-9. | Article | PubMed

22. Ding $H, X u$ Y, Wang $X$, Wang $Q$, Zhang L, Tu Y, Yan J, Wang W, Hui R, Wang CY and Wang DW. 9p21 is a shared susceptibility locus strongly for coronary artery disease and weakly for ischemic stroke in Chinese Han population. Circ Cardiovasc Genet. 2009; 2:338-46. | Article | PubMed

23. Castro de Guerra D, Figuera Perez C, Bravi CM, Saunier J, Scheible M, Irwin J, Coble MD and Rodriguez-Larralde A. Sequence variation of mitochondrial DNA control region in North Central Venezuela. Forensic Sci Int Genet. 2012; 6:e131-3. I Article I PubMed

\section{Citation:}

Jimenez Y, Vívenes de Lugo M and Castro de Guerra D. rs10757278 (9p21 region) affects the risk of arterial thrombosis in male individuals from the state of anzoátegui, Venezuela. J Genet Stud. 2013; 1:1. http://dx.doi.org/10.7243/2054-1112-1-1 